\title{
Image
}

\section{Young woman with chronic diarrhea}

\author{
Sunit K. Shukla, Vinod K. Dixit
}

Department of Gastroenterology, IMS, BHU, Varanasi, Uttar Pradesh, India

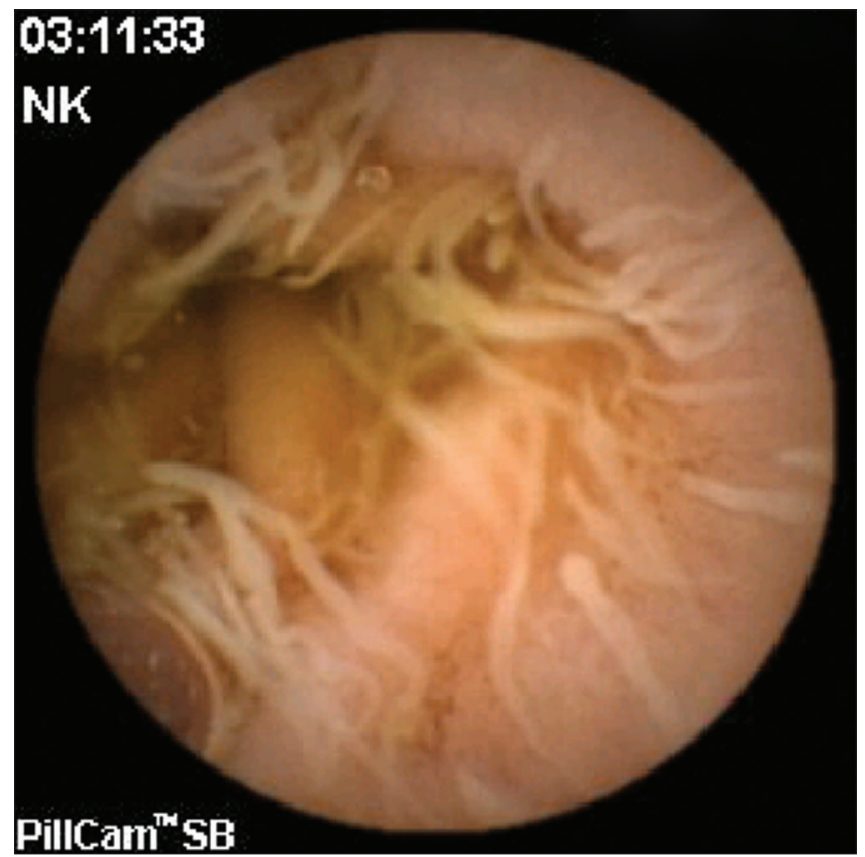

Figure 1: Dwarf tape worms (Hymenolepis nana) in proximal jejunum among normal appearing villi

\section{Capsule endoscopy image of the} proximal small intestine in a patient with chronic diarrhea.

What is the diagnosis?
Image provided by:

Dr. Sunit Shukla

Durga Kund, Varanasi, India

Email: sunitshuklabhu@gmail.com

\section{Access this article online}

\begin{tabular}{|l|c|}
\hline \multicolumn{2}{|c|}{ Access this article online } \\
\hline \multirow{2}{*}{$\begin{array}{l}\text { Website: } \\
\text { www.jdeonline.in }\end{array}$} & Quick Response Code \\
\hline DOI: & \\
10.4103/0976-5042.165704 & \\
&
\end{tabular}

This is an open access article distributed under the terms of the Creative Commons Attribution-NonCommercial-ShareAlike 3.0 License, which allows others to remix, tweak, and build upon the work non-commercially, as long as the author is credited and the new creations are licensed under the identical terms.

For reprints contact: reprints@medknow.com

How to cite this article: Shukla SK, Dixit VK. Young woman with chronic diarrhea. J Dig Endosc 2015;6:115-6. 


\section{Answer}

An adolescent female who presented with complaint of chronic watery diarrhea. General and systemic physical examination was normal. On capsule endoscopy, the proximal small intestine was infested with large number of dwarf tapeworms. Dedicated, repeated stool examination showed eggs of Hymenolepis nana in one of the three stool examination reports. She improved with a single dose of praziquantel $25 \mathrm{mg} / \mathrm{kg}$ body weight.
H. nana or dwarf tapeworm is one of the most common cestode parasitizing human species and is common in developed as well as developing countries. H. nana rarely cause symptom. Infestation with more than 2000 worms can cause enteritis, abdominal pain, diarrhea, loss of appetite. Stool examinations neither indicate the degree of infestation nor differentiate a symptomatic from silent infestation. Thus, empirical therapy in suspected cases may be optimal. Praziquantel is the treatment of choice but is not a widely prescribed antihelminthic in Indian subcontinent. 